\title{
THE EFFECT OF PRICE PERCEPTION AND SERVICE QUALITY ON BRAND IMAGE FOR IMPROVING INTEREST IN USING GO-JEK (Study On GO-JEK In Semarang City)
}

\author{
Septy Setia Nugraha \\ Master of Management, Faculty of Economics and Business, Diponegoro University
}

\begin{abstract}
This research is conducted to test how big influence of price perception and service quality to brand image in increasing interest to use go-jek. Samples were taken from the company's services gojek number of 110 respondents, Structural Equation Modeling (SEM) was run by AMOS software, was used to analyze the data obtained, the analysis shows that the perception of price and service quality has a positive effect on the image of the brand in increasing interest in using.

The most dominant variable in influencing interest in using with the mediation of brand image is the perception of price and service quality. The suggested implications are that the mock companies are able to create brand image through competitive prices, easy payment systems and improved service quality
\end{abstract}

Keywords: brand image, Service quality, interest in using, Go-Jek, price perception.

\section{INTRODUCTION}

This mature technology experiencing extremely rapid, marked by the fusion of information technology with communications technology that generates system information. One result pe fused between computer technology and telecommunications that works is the Internet. Evidence of the success of the internet is the proliferation of application programs that run over the Internet, including mobile applications on smartphones.

According BeritaNet (2015), GO-JEK applications has increased the number of downloads in the three months since it was first launched. In January 
2015, the app was downloaded 32,360 times, increasing in February to 81,843 times, and rising back to 131,795 times in March 2015.

The reason people nowadays prefer to use Go-Jek as motorcycle online is a public perception that motorcycles online judge is more practical than a conventional motorcycle, users can book via the internet without having to jump in the field to find a motorcycle taxi. Customers also feel safe because of Go-Jek is integrated under the auspices of an institution that will be greater customer confidence, and rates have been standardized so that customers do not have to bargain with the driver.

In this research will be analyzed the influence of price perception, service quality and brand image in increasing interest to use GO-JEK Semarang city. Research on GO-JEK is with respondents who use GO-JEK services for go-ride, go-car, go-send, go-food, go-box facilities. GO-RIDE is a facility provided by GOJEK for consumers in terms of delivering and picking up consumers from a place and to a place that has been booked through the GO-JEK app. GO-FOOD is a GO-JEK app with online ordering facility through GO-JEK app.

The research problem is there are still differences of opinion on perceptions influence the price and quality of service to the image of e $\mathrm{k}$ mer increase interest in using, so that the problem in this research is how to build the image of mer e $\mathrm{k}$ through the perception of price and quality of services to increase interest in using Go-Jek in particular in the city of Semarang. From the formulation of the problem, research questions are as follows:

1. Is there a positive influence between price perception on brand image?

2. Is there a positive influence between price perceptions of interest in using?

3 . Is there a positive influence between the quality of service on brand image?

4. Is there a positive influence between the quality of service on interest to using?

5. Is there a positive influence between the brand image and the intertest of using?

Thus, based on the above thought and explanation can be drawn hypothesis as follows:

$\mathrm{H} 1$ : Price perceptions have a positive effect on brand image.

$\mathrm{H} 2$ : Service quality positively affects brand image

H3: Brand image has a positive effect on buying interest

$\mathrm{H} 4$ : Price perceptions have a positive effect on buying interest

H5: Quality of service has a positive effect on buying interest. 


\section{RESEARCH METHOD}

Objects in this study are the users of GO-JEK in the city of semarang. Primary data is the kind of data obtained through the direct process with a register (Wiriaatmadja, 2007). Primary data in this study was obtained in the form of questionnaires submission based on predetermined variables given optional alternative answers. This primary data is then used for input data as hypothesis submission.

Secondary data is the type of data that the recording was not done alone but is already available in the field (Wiriaatmadja, 2007). Secondary data in this study was obtained from the driver GOJEK Semarang. Samp in $p$ enelitian el using accidental sampling method, which takes respondents in the sample by coincidence, that anyone who is kebetuan met with researchers can dgunakan as a sample when the people who happened to be found suitable as a data source (Sugiyono, 2004).

The ideal and respresentative size of respondents is dependent on the number of indicators available and multiplied by $5-10$. Thus the respondents for this study are as follows: The number of indicators: 15 Respondents: $15 \times 5=75$. Thus the sample used for the respondents in this study is numbered 110 people, this is done against all possible risks minimum value that will be obtained later.

The data required, namely the identity of respondents and respondents to the questionnaire were distributed. Data collection was done through questionnaires representing latent variables and observation variables in the study. The research questionnaire contained a statement strongly agreeing to disagree using Likert scale as its reference, Likert scale is used to measure attitudes, opinions and perceptions of a person or group of people. Where each statement is made using scale 1 criteria strongly disagree to 7 to strongly agree.

\section{DATA ANALYSIS AND DISCUSSION}

Subsequent analysis is the analysis of Structural Equation Model (SEM) as a full model, after analysis of the level of the indicators unidimensionalitas forming latent variables tested by confirmatory factor analysis. Analysis of the data processing at the stage of full model SEM carried out to test the suitability and statistical tests. 
Figure 1

Path Diagram

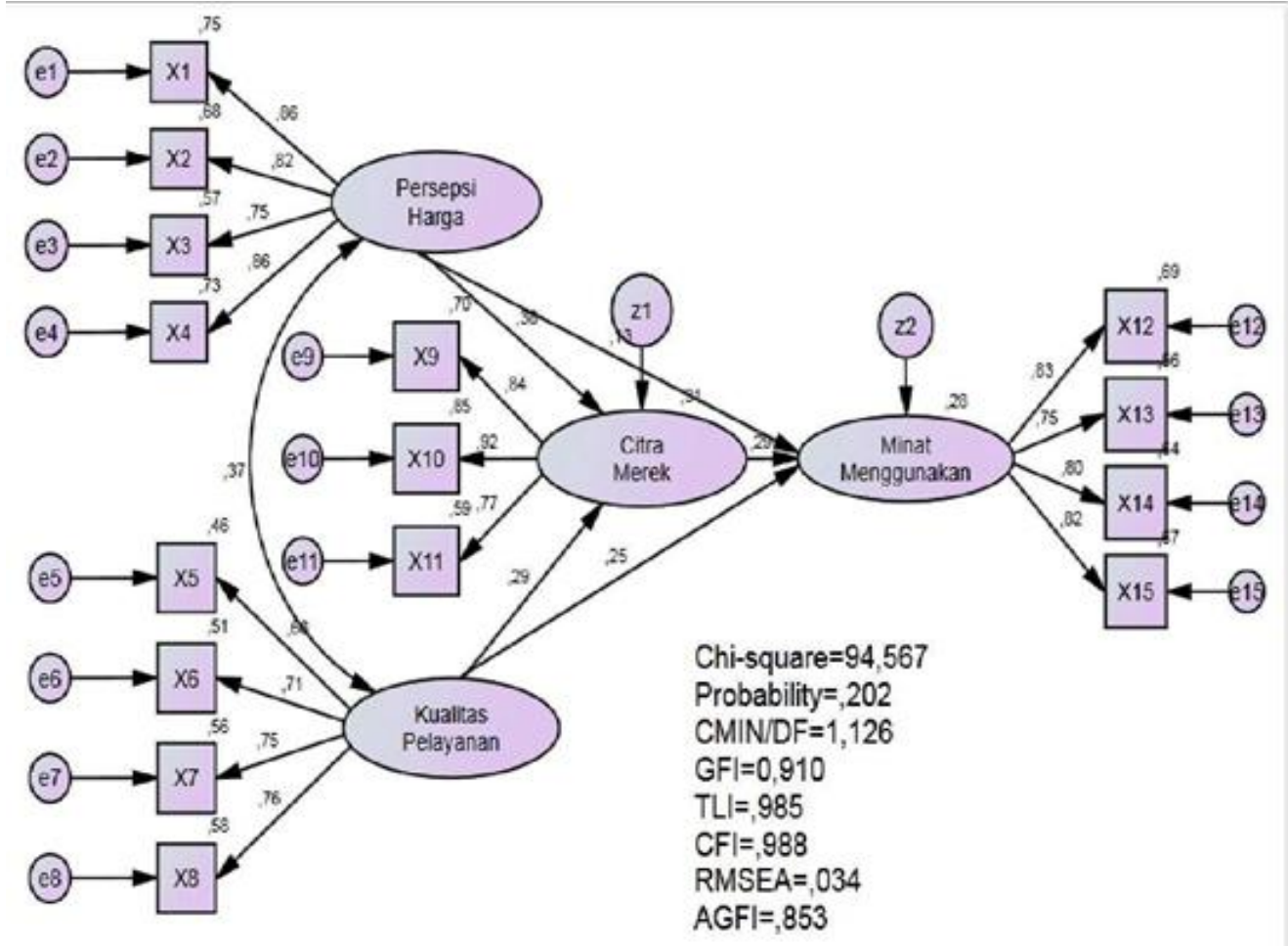

Test of the hypothesis models suggest that this model fits the data or fit to the data used in the study are as te $r$ seen in table 1 below:

\section{Table 1}

\section{Model Feasibility Test Result}

Structural Equation Model (SEM)

\begin{tabular}{lccc}
\hline $\begin{array}{c}\text { Goodness of } \\
\text { Fit Index }\end{array}$ & Cut-off Value & Analysis Results & $\begin{array}{c}\text { Model } \\
\text { Evaluation }\end{array}$ \\
Chi - Square & Small $<121,773$ & 94,567 & Good \\
Probability & $\geq 0.05$ & 0.202 & Good \\
RMSEA & $\leq 0.08$ & 0.034 & Good \\
GFI & $\geq 0.90$ & 0.91 & Good \\
AGFI & $\geq 0.90$ & 0.853 & Marginal \\
CMIN / df & $\leq 2.00$ & 1,126 & Good \\
TLI & $\geq 0.95$ & 0.985 & Good \\
CFI & $\geq 0.95$ & 0.998 & Good \\
\hline
\end{tabular}

Source: Research data that is processed, 2017 
Table 2

Standardized Regression Weight

\begin{tabular}{lllr}
\hline & & & Estimate \\
\hline Brand_Image & $<---$ & Price Perception & 0.379 \\
Brand_Image & $<---$ & Service quality & 0.29 \\
Interests_Using & $<---$ & Price Perception & 0.129 \\
Interests_Using & $<---$ & Brand_Image & 0.288 \\
Interests_Using & $<---$ & Service quality & 0.248 \\
X12 & $<---$ & Interests_Using & 0.828 \\
X13 & $<---$ & Interests_Using & 0.748 \\
X14 & $<---$ & Interests_Using & 0.802 \\
X15 & $<---$ & Interests_Using & 0.816 \\
X4 & $<---$ & Price Perception & 0.855 \\
X3 & $<---$ & Price Perception & 0.752 \\
X2 & $<---$ & Price Perception & 0.823 \\
X1 & $<---$ & Price Perception & 0.864 \\
X11 & $<---$ & Brand_Image & 0.771 \\
X10 & Brand_Image & 0.923 \\
X9 & $<---$ & Brand_Image & 0.838 \\
X8 & $<---$ & Service quality & 0.761 \\
X7 & $<---$ & Service quality & 0.748 \\
X6 & S-- & Service quality & 0.714 \\
X5 & - & 0.679 \\
\hline
\end{tabular}

Source: Research data that is processed, 2017

After all assumptions can be met, then will be tested hypothesis as proposed in the previous chapter. 5 Testing the hypothesis this study was conducted based on the value of Critical Ratio (CR) of a causality of the processing of SEM seba gaimana in Table 3 below:

\section{Table 3}

Regression Weight Structural Equational Model

\begin{tabular}{lllrrrr}
\hline & & & Estimat & SE & CR & P \\
\hline Brand Image & $<---$ & Price Perception & 0.305 & 0.087 & 3,518 & $* * *$ \\
Brand Image & $<--$ & Service quality & 0.284 & 0.109 & 2,606 & 0.009 \\
Use Interests & $<---$ & Price Perception & 0.097 & 0.087 & 1,125 & 0.261 \\
Use Interests & $<---$ & Brand Image & 0.269 & 0.114 & 2,359 & 0.018 \\
Use Interests & $<---$ & Service quality & 0.227 & 0.109 & 2.082 & 0.037 \\
\hline
\end{tabular}

Source: Research data that is processed, 2017 


\section{Hypothesis Testing Discussion 1}

Estimated parameters for testing the effect of the price perception of the brand image showed $C R$ values of 3.518 and with a probability of 0,00 . Both values are obtained qualify for admission $\mathrm{H} 1$ is nila $\mathrm{i} C R$ amounted to 3.518 greater than 1.96 and a probability of 0,00 were less than 0.05 . Thus it can be concluded that price perceptions have a positive effect on Brand Image. The results of this study support the research conducted by Alwi (2013) that the perception of prices can affect the brand image.

\section{Hypothesis Testing Discussion 2}

Parameter estimation for testing the quality of service to the brand image showed $C R$ values of 2.606 and with a probability of 0.009 . Both values are obtained eligible for admission of $\mathrm{H} 2$ is the tilapia i $\mathrm{CR}$ amounted to 2.606 greater than 1.96 and a probability of 0,009 , which is less than 0.05 . Thus it can be concluded that service quality has a positive effect on brand image. The results of this study support research conducted by Silva et al (2006) in his research which shows that customer service becomes important in improving the company's brand image.

\section{Hypothesis Testing Discussion 3}

Parameter estimation for the perception of the price of the interest in using demonstrating the value $C R$ amounted to 1.125 and with a probability of 0,261 . Both values are not eligible for admission $\mathrm{H} 3$ that nila i CR amounted to 1.125 smaller than 1.96 and a probability of 0,261 greater than 0.05 . Thus it can be concluded that price perception has no effect on the interest of using. The results of this study do not support previous research conducted by Lien et al (2015) which shows the result that price perception can increase consumer buying interest.

\section{Hypothesis Testing Discussion 4}

Parameter estimation for testing of brand image to show interest in using $\mathrm{CR}$ value of 2,359 and with a probability of 0.018 . Both values are obtained qualify for admission $\mathrm{H} 4$ among the tilapia i CR amounted to 2.359 greater than 1.96 and a probability of 0,018 smaller than 0.05 . Thus it can be concluded that the brand image has a positive effect on interest in using. The results support the research conducted by Boshoff et al (2009) that the image of the brand is able to influence consumers to buy.

\section{Hypothesis Testing Discussion 5}

Parameter estimation for testing the quality of service to the interest in using showed CR values of 2.082 and with a probability of 0,037 . Both values are obtained qualify for admission $\mathrm{H} 5$ namely tilapia i CR amounted to 2.082 greater than 1.96 and a probability of 0,037 smaller than 0.05 . It can be concluded 
positively affects the quality of services of interest to use. The results of this study support research conducted by Research Tugiso et all (2016) that the quality of service is able to influence consumer buying interest.

\section{CONCLUSIONS AND SUGGESTIONS}

\section{Conclusions}

Hypothesis which has been proposed in this study are as many as five hypotheses, the conclusion of the fifth as follows:

1. The result of price perception test and brand image can be concluded that price perception have positive effect on brand image. Better perception of the price of a product/service will affect the improvement of the brand image.

2. Results of testing the quality of service and brand image can be concluded that service quality has positive influence on brand image. the better the quality of services that a given company will affect the improvement of the brand image.

3. The results of price perception and interest use test can be concluded that the perception of the price does not affect the interest of using. So the better the perception of the price of a product / service will not affect the increased interest in using.

4. The results of brand image testing and interest in using can be concluded that the brand image has a positive effect on interest in using. The better the brand image will affect the increased interest in using.

5. The results of service quality testing and interest use can be concluded that the quality of service has a positive effect on the interest of using. So the better the quality of services that a given company will affect the increased interest in using.

\section{Suggestions}

Further research can be done by looking at the limitations in this study. Here are suggestions for future research.

1. Future research should be done with a wider object especially to other cities in Indonesia.

2. Media interviews and questionnaires in subsequent research are advised to provide open-ended questions as detailed as possible that include broader questions to obtain as much information as possible.

3. In future research, it is suggested to add trust and risk perception variables to interest in using and doing more extensive research on consumer satisfaction 
and interest in reuse. The addition of variables is expected to improve results for the better.

\section{REFERENCES}

Aghekyan-Simonian, M., Forsythe, S., Suk Kwon, W., \& Chattaraman, V. (2012). The role of product brand image and online store image on perceived risks and online purchase intentions for apparel. Journal of Retailing and Consumer Services, 19(3), 325-331.

Alwi, S., Shahril, A.I. (2013). A framework to attain brand promise in an online setting. Journal Marketing Intelligence \& Planning, 31(5), 557-578.

Boshoff, C., Charlene, S., Shannon, W. (2009). The mediating effect of brand image and information search intentions on the perceived risks associated with online purchasing on a generically-branded website. Journal Management Dynamic, 18(4), 18-28.

Chao, R., \& Ping-Chu L., 2016). The Impact of Brand Image and Discounted Price on Purchase Intention in Outlet Mall: Consumer Attitude as Mediator. The Journal of Global Business Management, 12 (2), 119-128.

De La, M., Toldos-Romero, P., \& Orozco-Gómez, M. M. (2015). Brand personality and purchase intention. European Business Review Internet Research Iss Internet Research Iss Journal of Product \& Brand Management, 27(2), 462476.

Ferdinand, Augusty, 2002, Pengembangan Minat Beli Merek Ekstensi, Semarang: Badan Penerbit Universitas Diponegoro.

Hartono, J.M. (2007). Sistem informasi keperilakuan(edisi Revisi) Yogyakarta: C.V Andi Offset.

Huang, C., Szu-Wei, Y., Cheng-Yi, L., Pei-Chen, H. (2014). The Relationship Among Corporate Social Responsibility, Service Quality, Corporate Image And Purchase Intention. The International Journal of Organizational Innovation, 6 (3), 68- 84.

John C. Mowen, Michael Minor, 2002, Perilaku Konsumen, Jakarta: Erlangga.

Kim, H. W., Xu, Y., \& Gupta, S. (2012). Which is more important in Internet shopping, perceived price or trust? Electronic Commerce Research and Applications, 11(3), 241. 
Knapp, E Duane. 2001. The Brand Mindset. Yogyakarta: Andi.

Kotler, Philip, 2007, Manajemen Pemasaran, Edisi Keduabelas, Indeks, Jakarta.

Kotler, Philip. 2009. Manajemen Pemasaran. Jakarta : Erlangga.

Kurniawan, H., Harry, S., \& Ahyar Y. (2016). Pengaruh Kualitas Produk, Kualitas Layanan, Dan Persepsi Harga Terhadap Nilai Pelanggan Dalam Meningkatkan Minat Beli (Studi Pada Konsumen Produk Batu Potong Besi 4 Inch Merek Wd Di Jawa Tengah). Jurnal Sains Pemasaran Indonesia Vol. Xv No.1 Pp.46-61.

Kuster, I., Vila, N., \& Canales, P. (2016). How does the online service level influence consumers??? purchase intentions before a transaction? A formative approach. European Journal of Management and Business Economics, 25(3), 111-120.

Lee, G.-G., \& Lin, H.-F. (2005). Customer perceptions of e-service quality in online shopping. International Journal of Retail \& Distribution Management Online Information Review Internet Research (Vol. 33).

Lee, M. 2009. Factors influencing the adoption of internet banking: An integration of TAM and TPB with perceived risk and perceived benefit. Electronic Commerce Research and Applications 8, pp. 130-141.

Lien, C.H., Miin, J.W., Li, C.H., Kuo, L.W. (2015). Online hotel booking: The effects of brand image, price, trust and value on purchase intentions. Journal Asia Pasific Management, 20, 212-218.

Lien, C. H., Wen, M. J., Huang, L. C., \& Wu, K. L. (2015). Online hotel booking: The effects of brand image, price, trust and value on purchase intentions. Asia Pacific Management Review, 20(4), 210-218.

Martín, S. S., Camarero, C., \& José,

R. S. (2011). Dual effect of perceived risk on cross-national e-commerce. Internet Research, 21(1), 46-66.

Maulana, R., Kezia K. (2014). Pengaruh Kualitas E-Service Terhadap Minat Beli Konsumen (Studi Kasus Pada Website Koren Denim). Jurnal Manajemen, 13(2), 117-129.

Mohamad, R., Building, A., \& Ismail, N. A. (2010). Journal of Internet Banking and Commerce. Journal of Internet Banking and Commerce, 15(1), 1-11. 
Peter, J. P., Olson. J. C., (1999).

Perilaku konsumen dan strategi pemasaran, Edisi keempat (terjemahan). Jakarta : Erlangga.

Qadri, U. A. (2015). Measuring Service Quality Expectation and Perception Using SERVQUAL: A Gap Analysis. Business and Economics Journal, 6(3),

Sastradipoera, Komaruddin, 2003, Manajemen Marketing; Suatu Pendekatan Ramuan Marketing, Kappa Sigma, Bandung.

Setiawan, R., Adrian A. (2012). Effects of Perceived Trust and Perceived Price on Customers' Intention to Buy in Online Store in Indonesia. Journal of ASEAN Marketing, IV(1), 26-36.

Silva, R.V.D., Sharifah, F.S.A. (2006). Cognitive, affective attributes and conative, behavioural responses in retail corporate branding. Journal of Product \& Brand Management, 15(5), 293-305.

Solomon, Michael. L., Elnora W. Stuart, 2003, Marketing, 3Th Edition, Pearson Education, Prentice Hall.

Summers A.T., Belleau B.D., \& Xu Y. (2006). Predicting purchase intention of a controversial luxury apparel product. Journal of Fashion Marketing and Management, 11(4), 571-586.

Tjiptono,Fandi. 2002. Manajemen Jasa. Cetakan II. Yogyakarta: Andi Offset.

Tjiptono, Fandi. 2005. Pemasaran Jasa. Malang : Bayumedia.

Simamora, Bilson. 2002. Panduan Riset Perilaku Konsumen. Jakarta: PT. Gramedia. Pustaka Utama

Tugiso, I., Andi, T.H., Maria, M.M. (2016). Pengaruh Relationship Marketing, Keamanan, Kepercayaan Dan Kualitas Pelayanan Terhadap Keputusan Pembelian Online Shop Dan Loyalitas Konsumen Sebagai Variabel Intervening (Studi Kasus Pada Onlineshop "NUMIRA" Semarang). Journal of Management, 2(2), 1-18.

Lin, W. (2009). A study of relations among service quality differences, postpurchase behavior intentions with personality traits, and service recovery strategy as intervening variables. Journal of Commerce and Management, 19 (2), 137-157. 